Article

\title{
Omnichannel Banking Economy
}

\author{
Sergey A. Vasiliev and Eugene R. Serov* \\ International Banking Institute, Nevsky Prospect, 60, 191023 St Petersburg, Russia; ibispb@ibispb.ru \\ * Correspondence: serov@ibispb.ru
}

Received: 24 September 2019; Accepted: 4 November 2019; Published: 7 November 2019

\begin{abstract}
In modern market conditions, customers who purchase banking products require a high level of service. In particular, they require continuous real-time service with the ability to instantly "switch" between service channels. The article analyzed the economic component of the omnichannel sales management system in banking. The existing barriers to introducing omnichannels to the practice of banking management have been identified. The features of the calculation of individual elements of the cost of sales at various stages of the life cycle of sales (sales funnel) are considered. An economic-mathematical model for managing the cost and profitability of sales by selecting the optimal omnichannel chains was proposed. The omnichannel model of interaction with customers enables banks to simultaneously achieve several key goals of increasing their own business efficiency: increase sales while reducing their cost and improving the quality of customer service. The model can be used not only in banking, but also in other forms of retail business where it is possible to collect detailed statistics and build a factor analysis of conversion through a sales funnel.
\end{abstract}

Keywords: omnichannel (omni-channel) sales; sales funnel; cost of sales; customer relationship management (CRM); big data; robo-advisor

\section{Introduction}

In modern conditions, customers purchasing banking products require a high level of service. In particular, they require uninterrupted real-time maintenance with the ability to instantly "switch" between service channels. Omnichannel sales are transactions in which several channels take part in the sale of a single product unit. They are the predicted trend of the next few years of e-commerce (Koneva 2019). Several sales channels coordinated with each other give the customer the opportunity to place an order and receive the ordered product in a way that is convenient for them, without losing the feeling of interaction with the bank's brand. The bank, for its part, sees sales statistics in a single information store and can manage all channels at once (Koneva 2019).

The issue of "smart" omnichannel sales management is fairly new in the world of science. Its theoretical base has only begun to be formed. Studies in the banking sector have mainly focused on the implementation of various banking services (Shaikh and Karjaluoto 2015). Most empirical studies have not provided a clear understanding of the customer experience of omnichannel banking services (Tam and Oliveira 2017). Klaus and Nguyen (2013) explored the role of customer experience in online retail banking services and many studies have focused on different aspects of mobile banking (Sahoo and Pillai 2017). Understanding the factors associated with customer experience in interacting with banks via different channels is not only of interest for banks within the framework of a single ecosystem that creates a universal experience of omnibanking services (Komulainen et al. 2018). Understanding customer experience is recognized as one of the most important current research priorities (Marketing Science Institute 2016). In recent years, interest in managing customer service experience has grown significantly in marketing (Dube and Helkkula 2015). 
Omnichannel banking focuses on the principles of consistency, optimization, and seamlessness, with the aim to make the customer experience as satisfactory as possible (Komulainen and Makkonen 2018). The omnichannel approach should be seen as an evolution of the multichannel approach originating in the retail industry (Rosman 2015; Saghiri et al. 2017). According to studies in the retail sector, if the seller moves from a multichannel model to an omnichannel one, then the buyers of such a store will start spending $20 \%$ more money (Okorokov 2016). The difference between omnichannel and multichannel sales is the ability to continue the interaction started in one channel in another channel without the need to duplicate information, as well consistency of price of products and services in all channels.

Despite the general consensus at to the high economic efficiency of introducing the omnichannel approach (due to a multiple reduction in costs), there have been no specific economic calculations done, which reinforces the need for a more detailed analysis with the application of an economic model. The economy of remote retail for omnichannel retailers is determined by the total number of customer orders. According to experts, customers who buy goods and services through a multichannel sales model spend four times more on purchases than orders through monochannel retailers (Retail Pragmatist 2019).

According to IBM, multichannel experiences are no longer a competitive edge, but a "ticket to compete" for banks: a strategic prerequisite for the new era of a digital transaction (Centric Digital 2017). Banking is fundamentally a complex, service-oriented architecture (SOA) of many different systems that unite the different areas of an organization that manage discrete parts of customer experience. With omnichannel implementation, banks can use data collected throughout the customer's life cycle to create a seamless personalized experience that increases value and satisfaction, reducing maintenance costs (Obilisetty 2019).

The objective of this study was to analyze the economic component of omnichannel sales in banks. In the current market conditions for this business, characterized by a high level of competition with a decrease in market profitability, cost optimization is given primary attention. An effective way to optimize cost is not only to transfer operations from the traditional branch network to remote channels (Internet banking, website, call-center, bots, and other "robo-advisers"), but also to implement competent management omnichannel sales chains. That is, the organization of a system that allows you the sale process to be begun in one channel, to continue in another, and to be completed in the third, while maximizing the overall economic result in the form of profit from sales.

Practical cases of implementing the individual elements described in the Internet resources of the largest banks and other companies in the retail sector, as well as companies implementing IT solutions that support the multichannel sales model (Terrasoft 2019; Koneva 2019), are available mainly to market analysts only. Market analysts consider ready-made practical solutions for building sales through various channels (Internet sites of the company or its partners, mobile applications, social networks, blogs, offline channels). Mobile banking has already become the central driver of a completely customer-centered experience in the world of modern banking.

According to experts, "mobile transactions show a 90\% increase in cost savings when compared to an in-branch visit" (Centric Digital 2017). A total 65\% of customers already use more than one channel of interaction with their bank, and $80 \%$ of banks planned to use video for banking services by the end of 2018 (Centric Digital 2017).

In Sberbank, the share of retail sales in digital channels had already reached 20\% by 2017 (including $23 \%$ for deposits) and, according to the approved development strategy of Sberbank, the share of services provided in the digital retail bank should reach $60 \%$ by 2020 (Sberbank 2018). In Tinkoff Bank, $79 \%$ of sales are already made in remote channels (call center, Internet bank, bots), with the prospect of this share reaching $90 \%$ in the coming years (Tinkoff 2018).

According to studies, the cost of creating an omnichannel service model is one of the eight main areas of IT spending in banks (Terrasoft 2019). Provided that the solution platform is open and scalable, "the introduction of new remote channels should entail low additional costs" (Retail Pragmatist 2019) for 
interacting with customers and choosing individual offers with significant development of cross-selling of related products and services.

Knowledge of the customer experience allows the bank to differentiate its products and services to create superior customer value (Jaakkola et al. 2015). Understanding the banking experience is especially important for the banking business in order to increase customer reach, retention, operational efficiency, and market share (Skan et al. 2015).

Based on the above assumptions, this work proposes a methodology for managing the cost and profitability of omnichannel sales by identifying the key factors affecting efficiency, combined in an economic-mathematical model (Materials and Methods). In Section 3 (Results), the model was tested on a conditional example of one of the large Russian banks, and suggestions have been made in key areas for increasing the efficiency of practical applications of the model. Section 4 (Discussion) describes the limitations for implementing the model into banking management practice, as well as methodological assumptions in its construction. Section 5 (Conclusions) summarizes the key findings of the study and suggests directions for its possible development.

\section{Materials and Methods}

One of the key ideas of the model was to take into account the total cost of the sales process of one unit of the sold product of all activities leading to the final sale, including losses at all stages of the sales funnel (for transactions that did not reach the final sale), as well as all development-related costs associated with sales software support, marketing, and promotion.

In the management and marketing of a retail business, including banking, one of the key factors affecting the ultimate sales efficiency is the number of customers who are offered goods or services (customer flow).

A related indicator is the customer-to-sales conversion rate, which reflects the percentage of customers who ultimately entered into a sale and purchase transaction.

Sales of the product in the channel (SPch) for a selected period of time are equal to the product of the target customer flow entered into the channel $(C l F)$ by a statistically determined percentage of the conversion of this flow into sales (ChConv):

$$
\text { SPch }=C l F * \text { ChConv }
$$

On the other hand, factors also affecting the sales of the product in the channel are: specific sales productivity per employee $(S P r)$, channel resource (number of employees-QSt), and number of working days in a selected period of time when these employees work $(t)$ :

$$
S P c h=S P r * Q S t * t,
$$

Combining both equations allows us to set up a model of the relationship of the five above-mentioned factors (Equation (3)):

$$
\mathrm{ClF}{ }^{*} \mathrm{ChConv}=\mathrm{SPr}^{*} \mathrm{QSt}{ }^{*} t
$$

At the same time, the cost of sales of the product in the channel (CSCh) is equal to the product of the number of actions (operations) necessary to sell one unit of the product in the channel $(N)$, the standard time of each operation (Tn), and the cost of $1 \mathrm{~min}$ of employee channel $(\mathrm{CCh})(4)$ :

$$
\text { CSCh }=N^{*} T n^{*} C C h
$$

The cost of $1 \mathrm{~min}$ of employee work in the channel is a very convenient and universal indicator for calculating the cost of various processes, and is calculated based on the bank's management accounting 
data as the ratio of direct administrative and management expenses per channel to the number of channel "sellers", multiplied by their working time fund in minutes per month.

Direct administrative and management expenses include all payments related to labor remuneration (including taxes and deductions to state funds), as well as expenses for maintaining workplaces (rent, utility bills, communication channels, security, depreciation, property tax, etc.) If necessary, it is possible to take into account the indirect costs for labor and maintenance of workplaces for the management personnel administering the "sellers" of the channel.

The universal sales funnel can be divided into three consecutive stages:

(1) Bring the client a proposal with the aim of generating interest.

(2) Make a request for a product or service with an interested client.

(3) Conclude a contract with the client, with subsequent activation of the use of the product.

At each of these stages of the general sales cycle, work can be carried out by an employee, or by an automated "machine algorithm", in the various channels of interaction with the customer.

In the model and formulas, the stage number of the sales funnel is indicated by the lower index $(1,2,3$ - see Equation (5)).

For example, a customer was called by a call center employee, offering to issue a consumer loan. The client promised to think, and after a week he made an application for a loan and insurance via Internet banking. He then applied to the nearest bank office for a cash loan, or, during the next visit to the office to reissue the deposit, the client was offered a payment card. The client, already on his way home, made an order for the card in the online banking mobile application, having issued its delivery to his home by courier.

The total cost of the sales cycle is calculated as the product of the total sales duration of each sales cycle and the cost per minute of the employee of the channel carrying out operations in the cycle (Equation (5)):

$$
\text { CSCh }=N_{1} \times T_{1} \times C C h_{1}+N_{2} \times T_{2} \times C C h_{2}+N_{3} \times T_{3} \times C C h_{3}
$$

It is obvious that the number of actions for one sale depends exclusively on the percentage of conversion of "contacts" into "interests", "interests" into "bids", and "bids" into "contracts" within the framework of a universal "sales funnel". The higher the conversion percentage, the lower the number of operations. In assessing the cost of sales, costs are taken into account not only for those operations that ultimately led to the sale of the product, but also for all outstanding transactions and losses.

Thus, the model for assessing the value and profitability of sales serves as a tool for making complex management decisions for a number of interrelated parameters:

- $\quad$ target customer flow;

- conversion of the target customer flow into sales;

- $\quad$ the number of sellers in the channel;

- $\quad$ specific sales productivity for one seller in the channel for the period (day, month, quarter);

- $\quad$ the cost of 1 min of work channel employee;

- the standard time of one operation in the context of products, channels, stages of the sales cycle;

- the number of actions/operations required for the implementation of one sale of the product in the channel.

Moreover, in the framework of the omnichannel service model, the possibility of separate communication of each channel with customers at different stages of the sales funnel creates the potential to optimize costs by building omnichannel chains that minimize costs, which has been taken into account in the proposed model, which separately estimates the cost of each stage of the sales funnel. 


\section{Results}

By modeling the sales process using selected key factors affecting the overall effectiveness of transactions within the framework of a typical sales funnel, the following ways to increase efficiency were proposed. According to the model, in order to optimize the cost of sales, it is necessary to (Serov 2018):

(1) Reduce regulatory time for rendering operations, introducing new technologies, and optimizing processes;

(2) Reduce the cost of 1 min of work of an employee by selecting channels with the lowest cost of maintaining jobs;

(3) Reduce the number of transactions required for a sale, automating the processes and selecting channels or sales scenarios with the highest conversion of target client flow into sales.

To test the working capacity in practical conditions, the omnichannel sales cost management model for credit organizations was tested in 2018 at a large Russian bank with a wide branch network and developed alternative sales channels (using conditional figures that were close to reality). In that bank, sales of products were organized through four different channels: branch network, call center, field agent sales to companies (or by courier to a place convenient for the client), and Internet banking or bank website.

At the first stage, for each of these channels, the cost of $1 \mathrm{~min}$ of work for one "seller" was estimated (see Table 1).

So, in this example, the highest cost of 1 min of work $(0.37 \mathrm{cu})$ was from one seller in the branch network channel, and the smallest $(0.07 \mathrm{cu})$ was in the Internet channel.

At the second stage of modeling, the cost of sales of one unit of a conditional product in the channel (excluding the costs of developing and maintaining software products, marketing, and promotion) was estimated using Equation (4). A conditional calculation example is given in Table 2.

As can be seen from the model, for the sale of one product in Channel 1, the branch network, it was necessary:

- $\quad$ to offer the service to 50 customers, of which $10 \%$ (5 customers) will be interested;

- $\quad$ to offer to issue an application to 5 interested clients, 40\% (2 conditional customers) of which will eventually accept;

- $\quad$ only $50 \%$ of these applicants ( 1 client) will reach stage of contract execution, passing the application approval procedure, and wishing to use the product.

The total sales conversion of the full cycle in Channel 1 thus amounted to $2 \%=(10 \% \times 40 \% \times 50 \%)$, i.e., of the 50 customers who were offered the product, only 1 was brought to the conclusion of the contract.

According to the time standard for one timed operation, the procedure for the initial offer of Product 1 in Channel 1 lasted $2 \mathrm{~min}$, with filling out an application at $15 \mathrm{~min}$, and checking, concluding a contract, and issuing taking $20 \mathrm{~min}$.

Multiplying the number of operations at the time of each operation and the cost of 1 min of work of the seller, management can obtain the cost of sales of Product 1 in the channel at direct costs: 79 cu, of which the main costs fall in stages I and II of the sales funnel ( $37 \mathrm{cu}$ and $27 \mathrm{cu}$ ), because it was at these stages that the main losses in conversion of the flow into transactions occurred.

The costs of developing and maintaining software, as well as marketing and promotion, were allocated to products and channels in the proportions agreed upon within the bank. First, there was a distribution of the total cost item for individual products, then within each product into the channels, and finally within each channel in proportion to the actual sales for the period in units. An example distribution is shown in Table 3. 
Table 1. Calculation of the cost of $1 \mathrm{~min}$ of work channel employee.

\begin{tabular}{|c|c|c|c|c|c|}
\hline Name of Sales Channel & Number of Sellers & $\begin{array}{l}\text { Payroll with Deductions } \\
\text { (Thousand/Month) }\end{array}$ & $\begin{array}{l}\text { Other Direct Costs * } \\
\text { (Thousand/Month) }\end{array}$ & $\begin{array}{l}\text { The Cost of } 1 \text { Minute of Work for } \\
\text { One Channel Seller (from Labor } \\
\text { Costs, cu) cu }\end{array}$ & $\begin{array}{l}\text { The Cost of } 1 \text { Minute of Work for } \\
\text { One Channel Seller (from Total } \\
\text { Direct Costs, cu) }\end{array}$ \\
\hline & 1 & 2 & 3 & $4=2 / 1 / \mathrm{FWT}^{* *}$ & $5=(2+3) / 1 /$ FWT $* *$ \\
\hline Channel 1 (Branch) & 500 & 800 & 1000 & 0.6 & 0.37 \\
\hline Channel 2 (Call center) & 150 & 180 & 60 & 0.12 & 0.16 \\
\hline Channel 3 (Direct Sales by Agents) & 40 & 56 & 20 & 0.14 & 0.19 \\
\hline Channel 4 (Internet Banking) & 10 & 24 & 8 & 0.06 & 0.07 \\
\hline Channel 1 (Branch) & 500 & 800 & 1000 & 0.16 & 0.37 \\
\hline
\end{tabular}

* the cost of sellers takes into account the direct costs of rent, utilities, depreciation, and taxes, as well as allocated payroll management staff. It does not include software $*$ the cost of sellers takes into account the direct costs of rent, utilities, depr
development/maintenance and marketing costs. ** FWT-working time fund.

Table 2. Calculation of the cost of sales at direct costs.

\begin{tabular}{|c|c|c|c|c|c|c|c|}
\hline $\begin{array}{l}\text { Name of Sales } \\
\text { Channel }\end{array}$ & $\begin{array}{l}\text { The Cost of } 1 \text { Min of } \\
\text { the Channel Seller, cu }\end{array}$ & $\begin{array}{l}\text { Get the Client's } \\
\text { Interest }\end{array}$ & $\begin{array}{c}\text { Accept an Application } \\
\text { from the Client by Interest }\end{array}$ & $\begin{array}{l}\text { Checkout Service at the } \\
\text { Request of the Client }\end{array}$ & $\begin{array}{l}\text { Get the Client's } \\
\text { Interest }\end{array}$ & $\begin{array}{c}\text { Accept an Application } \\
\text { from the Client by Interest }\end{array}$ & $\begin{array}{l}\text { Checkout Service at the } \\
\text { Request of the Client }\end{array}$ \\
\hline & & \multicolumn{3}{|c|}{ Duration of the operation (minutes) } & \multicolumn{3}{|c|}{ Number of operations per sale (based on \% conversion) } \\
\hline Branch & 0.37 & 2 & 15 & 20 & 50 & 5 & 2.0 \\
\hline Call center & 0.16 & 2 & 10 & 1 & 31 & 6 & 2.5 \\
\hline Sales by Agents & 0.19 & 8 & 5 & 10 & 38 & 29 & 2.9 \\
\hline Internet Bank & 0.07 & 0.5 & 1 & 1 & 185 & 3,3 & 3.3 \\
\hline \multirow[t]{2}{*}{$\begin{array}{l}\text { Name of sales } \\
\text { channel }\end{array}$} & $\begin{array}{l}\text { Get the Client's } \\
\text { Interest }\end{array}$ & $\begin{array}{l}\text { Accept an Application } \\
\text { from the Client } \\
\text { by Interest }\end{array}$ & $\begin{array}{l}\text { Checkout Service at the } \\
\text { Request of the Client }\end{array}$ & Full Cycle & $\begin{array}{l}\text { Get the Client's } \\
\text { Interest }\end{array}$ & $\begin{array}{l}\text { Accept an Application } \\
\text { from the Client by Interest }\end{array}$ & $\begin{array}{l}\text { Checkout Service at the } \\
\text { Request of the Client }\end{array}$ \\
\hline & \multicolumn{4}{|c|}{$\begin{array}{l}\% \text { conversion by sales funnel } \\
\text { (to the previous stage) }\end{array}$} & \multicolumn{3}{|c|}{ Cost of sales at direct costs, cu } \\
\hline Branch & $10 \%$ & $40 \%$ & $50 \%$ & $2 \%$ & 37 & 27 & 1 \\
\hline Call center & $20 \%$ & $40 \%$ & $40 \%$ & $3 \%$ & 10 & 10 & 0.4 \\
\hline Sales by Agents & $75 \%$ & $10 \%$ & $35 \%$ & $3 \%$ & 59 & 28 & 6 \\
\hline Internet Bank & $2 \%$ & $100 \%$ & $30 \%$ & $1 \%$ & 7 & 0.2 & 0.2 \\
\hline
\end{tabular}


Table 3. Distribution to products and channels of software costs and marketing.

\begin{tabular}{|c|c|c|c|c|c|}
\hline $\begin{array}{l}\text { Name of Product/Sales } \\
\text { Channel }\end{array}$ & $\begin{array}{l}\text { Channel } 1 \\
\text { (Branch) }\end{array}$ & $\begin{array}{l}\text { Channel } 2 \\
\text { (Call Centre) }\end{array}$ & $\begin{array}{c}\text { Channel } 3 \\
\text { (Direct Sales } \\
\text { by Agents) }\end{array}$ & $\begin{array}{l}\text { Channel } 4 \\
\text { (Internet } \\
\text { Banking) }\end{array}$ & Total \\
\hline \multicolumn{6}{|c|}{ Product/channel share in software development and maintenance costs } \\
\hline Product 1 (consumer loans): & $1 \%$ & $1 \%$ & $1 \%$ & $7 \%$ & $10 \%$ \\
\hline Product 2 (deposits): & $0 \%$ & $1 \%$ & $0 \%$ & $4 \%$ & $5 \%$ \\
\hline \multicolumn{5}{|c|}{$\begin{array}{l}\text { Distribution of monthly average costs for software development and maintenance based on the } \\
\text { share of the product/channel (million cu) }\end{array}$} & 0.40 \\
\hline Product 1 (consumer loans): & 0.004 & 0.004 & 0.004 & 0.028 & 0.04 \\
\hline Product 2 (deposits): & & 0.004 & - & 0.016 & 0.02 \\
\hline \multicolumn{6}{|c|}{ Share of product/channel in marketing and promotion costs } \\
\hline Product 1 (consumer loans): & $5 \%$ & $6 \%$ & $1 \%$ & $8 \%$ & $20 \%$ \\
\hline Product 2 (deposits): & $10 \%$ & $0 \%$ & $0.1 \%$ & $5 \%$ & $15 \%$ \\
\hline \multicolumn{5}{|c|}{$\begin{array}{l}\text { Distribution of average monthly expenses for marketing and promotion based on the share of the } \\
\text { product/channel (million cu) }\end{array}$} & 0.8 \\
\hline Product 1 (consumer loans): & 0.04 & 0.05 & 0.01 & 0.06 & 0.2 \\
\hline Product 2 (deposits): & 0.08 & - & 0.001 & 0.04 & 0.1 \\
\hline \multicolumn{6}{|c|}{ Average monthly sales of products in channels (pcs) } \\
\hline Product 1 (consumer loans): & 10,000 & 5,000 & 500 & 10,000 & 25,500 \\
\hline Product 2 (deposits): & 20,000 & 1,000 & 300 & 30,000 & 51,300 \\
\hline \multicolumn{6}{|c|}{ The cost of software development/maintenance, marketing and promotion based on $1 \mathrm{pc}$ of sales (cu) } \\
\hline Product 1 (consumer loans): & 4.4 & 10.4 & 24.0 & 9.2 & \\
\hline Product 2 (deposits): & 4.0 & 4.0 & 2.7 & 1.8 & \\
\hline
\end{tabular}

In this example, $10 \%$ of the average monthly expenses for software development and maintenance (0.04 million out of 0.4 million $\mathrm{cu}$ ) were allocated to Product 1 . In the context of sales channels, the main emphasis in financing was placed on the Internet channel $(0.028$ million cu or $70 \%$ of the total). Similarly, the costs of marketing and promotion can be attributed to products and channels. For example, $20 \%$ of the total amount of 0.8 million cu on Product 1 (of which $40 \%=0.06$ million cu per Internet banking channel).

As a result, based on the units of product sold, in the context of sales channels, the impact of the costs of software development and maintenance, and marketing and promotion ranged from $1.8 \mathrm{cu}$ (deposits in online channels) to $24 \mathrm{cu}$ (consumer loans in direct agent sales).

As can be seen from the calculation, the above specific costs decreased the greater the scale of sales of the product channel. Summing up the previously calculated cost of sales of the product at direct costs with the additional unit costs for software development and maintenance, as well as marketing and promotion, it was possible to calculate the total cost (see Table 4).

Thus, for example, the total cost of sales of one unit of product in the branch network channel is: $78.6+4.4=83 \mathrm{cu}$

Due to the distribution of operations, conversion, and cost between the stages of the sales funnel, the model allowed calculation of the cost not only of sales of the full cycle in a single channel, but also of omnichannel sales chains.

For example, if, instead of selling a product at all stages through one channel (branch network full cycle chain: $\mathrm{Br}-\mathrm{Br}-\mathrm{Br}$ ), the first stage, "interest the customer", happens through live communication in the branch network, and then the client navigates to apply for and receive a loan to his account via the digital Internet banking channel (stages 2 and 3 of the sales funnel), then the cost of the received omnichannel chain (Br-IB-IB) for the bank could decrease 2-fold: $40.4+0.4+0.4=41.2$ cu instead of $40.4+27.8+14.8=83.0 \mathrm{cu}$.

The cost could be reduced by optimizing the use of the resource of branch network sellers participating only in the first stage of interaction with the client. This, despite a slight decrease in the overall percentage of conversion of the target client flow into transactions (from $2.0 \%$ to $1.5 \%$ with 
a loss of human contact), would lead to an increase in bank profits both per unit of sold products (from 217 up to $259 \mathrm{cu}$ ) and per seller per month (from 4.3 to 7.3 thousand $\mathrm{cu}$ ) (see Table 5).

Table 4. Calculation of cost of sales, taking into account the cost of software and marketing.

\begin{tabular}{|c|c|c|c|c|c|c|c|c|c|}
\hline $\begin{array}{l}\text { Name of Sales } \\
\text { Channel }\end{array}$ & $\begin{array}{l}\text { Cost of Sales } \\
\text { at Direct Costs } \\
\text { (cu) }\end{array}$ & $\begin{array}{l}\text { Get the } \\
\text { Client's } \\
\text { Interest }\end{array}$ & $\begin{array}{c}\text { Accept an } \\
\text { Application } \\
\text { from the Client } \\
\text { by Interest }\end{array}$ & $\begin{array}{l}\text { Checkout } \\
\text { Service at the } \\
\text { Request of the } \\
\text { Client }\end{array}$ & $\begin{array}{l}\text { Full } \\
\text { Cycle }\end{array}$ & $\begin{array}{l}\text { Get the } \\
\text { Client's } \\
\text { Interest }\end{array}$ & $\begin{array}{c}\text { Accept an } \\
\text { Application } \\
\text { from the Client } \\
\text { by Interest }\end{array}$ & $\begin{array}{l}\text { Checkout } \\
\text { Service at the } \\
\text { Request of the } \\
\text { Client }\end{array}$ & $\begin{array}{l}\text { Full } \\
\text { Cycle }\end{array}$ \\
\hline & & \multicolumn{4}{|c|}{$\begin{array}{l}\text { Unit costs for software development and maintenance, } \\
\text { marketing, and promotion (cu)* }\end{array}$} & \multicolumn{4}{|c|}{$\begin{array}{l}\text { The total cost of sales of } 1 \text { unit of product in the channel } \\
(\mathrm{cu})\end{array}$} \\
\hline Branch & 78.6 & 3.9 & 0.4 & 0.2 & 4.4 & 40.4 & 27.8 & 14.8 & 83.0 \\
\hline Call Center & 20.7 & 8.1 & 1.6 & 0.7 & 10.4 & 18.3 & 11.8 & 1.1 & 31.1 \\
\hline $\begin{array}{l}\text { Direct Sales by } \\
\text { Agents }\end{array}$ & 91.9 & 13.2 & 9.9 & 1.0 & 24.0 & 71.9 & 37.4 & 6.5 & 116 \\
\hline Internet Bank & 7.4 & 8.9 & 0.2 & 0.2 & 9.2 & 15.7 & 0.4 & 0.4 & 16.6 \\
\hline
\end{tabular}

* distribution at sales stages is based on the ratio of sales funnel conversions.

Table 5. Omnichannel sales chain scenario parameters.

\begin{tabular}{ccc}
\hline Name of the Indicator & Br-Br-Br & Br-IB-IB \\
\hline Target client flow per month, thousand clients & 500 & 417 \\
Conversion of target flow to sales (\%) & $2.0 \%$ & $1.2 \%$ \\
Specific sales productivity (pcs. per day for one employee) & 1.0 & 1.3 \\
The number of sellers & 500 & 177 \\
Omnichannel chain sales per month, thousand pieces & 10 & 5 \\
The cost of one sale (cu) & 83.0 & 41.2 \\
Omnichannel chain profit per month (thousand cu) & 2170 & 1294 \\
Profit on 1 unit of sales (cu) & 217 & 259 \\
Profit per one seller per month (thousand cu) & 4.3 & 7.3 \\
\hline
\end{tabular}

Similarly, the model was tested in other omnichannel sales chain optimization scenarios with a call center and direct sales agents. This made it possible to calculate the break-even points for each chain and economically justify investment in the development of these channels with the redistribution of the target client flow along with the resource of sellers to more profitable channels. Based on the practical testing results of the model, the most optimal (with business process parameters that existed at the time of testing) omnichannel sales chain for development was the process wherein the service was offered and the application was filled out (by voice) via the call center, and the conclusion of the contract with money transfer was made via Internet banking (the cost of sales of one loan was $\$ 30$, with the conversion of the target customer flow to sales at $3.2 \%$ ).

\section{Discussion}

One of the issues debated in building the model was the choice of method by which to allocate the costs of IT, marketing, and promotion per product. Due to the fact that it is practically impossible to accurately determine the proportions of the distribution of these expenses in proportion to the time spent and advertising budgets in the context of individual products and stages of the sales funnel, it was proposed that the above costs be allocated in proportion to the real structure of sales of banking products (either from the previous period or the plan for the next period). As the accuracy of statistics for assessing sales and processes in various dimensions (time, units, financial result) increases, the approaches to allocation and the model can be improved.

Another point of discussion in the process of testing the model was the question of correctly taking into account the specifics of the direct sales channel by agents. This was due to the need to choose an algorithm to distribute costs "on the road" to customers and then, if necessary, again to the bank office, between the stages of the sales funnel. As a result, an agreement was reached that these costs would be entirely allocated to the first stage of the sales funnel (to bring to the client a proposal with the aim of generating interest) in proportion to the share of the product in the product package offered to the client. The time for simultaneous voicing of the bank's proposals to a group of clients 
during presentations to enterprises was normalized based on the average number of participants in a group presentation, as well as the above on-the-road time allocated to the product.

The third aspect discussed during the implementation of the model was the question of the completeness and frequency of accounting for all customer contact activities within the sales funnel. One proposed strategy was the creation of a unified information system for recording the above activities on a monthly basis. However, according to the testing results, this approach was found to be very costly, since it required significant time costs for the employees of the analytical department, or huge investments in IT. Instead, the project management decided to use a ready-made analytical factor analysis of the phased transformation of customer contacts into transactions, which determined the percentage of customers who were transferred to the next stage of the sales funnel. Based on the available percentage of factor analysis, management can present a "countdown" of the number of actions at each stage necessary to conclude a deal with a client, which was applied in the model, updated at least quarterly. As the integrated analytics of the omnichannel sales model develops, it will be possible to move to direct accounting of operations at each stage of the sales funnel.

In the process of analyzing the theoretical base and practical application cases, the following limitations (barriers) were identified that impeded the implementation of an omnichannel sales model and cost management of an omnichannel sales chain in banking:

A large number of products and processes needed to be reengineered and automatized during the implementation of the omnichannel approach, both from our own company and from partner companies in the sales process. Significant capital expenditures on the development and maintenance of software and the purchase of equipment can be quickly paid for only with large-scale work on a product or project. These product and process upgrades include:

(1) A large number of IT systems are needed to account for various products. For example, even in one bank, sales of even the bank's own products might be counted in different information systems. The exchange of information on the non-bank products sold by partner companies with the IT systems of these partners is carried out, as a rule, in offline mode with a certain frequency. Thus, support for the omnichannel model when outsourcing part of the functions is also significantly hampered.

(2) The need to ensure a high degree of protection of information and customer accounts, especially with remote identification and services. This requires a centralized anti-fraud system covering all channels (Terrasoft 2019). The conservatism of certain clients and client segments (for example, Russian pensioners) using digital services wishing to receive documents on paper with live signatures must also be considered.

(3) Product-centric (instead of customer-centric) cultures (Maat 2017) are needed.

(4) Employees of different channels must be motivated to obtain results from sales in the implementation of their own KPI to achieve the planned targets and to receive a bonus. With omnichannel sales, it is important not only to take into account the contribution of each participant in the sales chain, but also, if possible, to avoid a double and triple accounting of bonuses for the same transaction, without going beyond the required overall profitability of the product's business.

These aforementioned restrictions will determine future areas of scientific and practical research on the topic of increasing efficiency of sales of banking (and not only banking, but also other retail products) via the introduction of an omnichannel approach.

\section{Conclusions}

Centralized analysis and control of interaction with customers at all stages and in all channels allows banks to significantly increase their targeting and service flexibility, reducing the time to market for products. A complete comprehensive analysis of the entire sales funnel makes it possible to control their cost, selecting the most optimal omnichannel chains. In calculating the cost of sales, it is necessary 
to take into account not only the direct costs of sales to customers who have made purchase transactions, but also all the losses throughout the whole sales funnel cycle, the costs of developing and maintaining information systems, and the costs of marketing and promotion.

As a result of this study, the main advantages of introducing an omnichannel model were identified, with the aim of improving management efficiency; the key factors for inclusion in the model were also identified, as well as the main barriers to implementation. The omnichannel model of interaction with customers will enable banks to simultaneously achieve several key goals of increasing their own business efficiency:

(1) Sales growth due to an increase in the frequency of interaction with customers while minimizing the loss of "unsatisfied" customers at the stage of the transaction life cycle;

(2) Improving the quality of customer service by providing access to products and services $24 / 7$ and saving customers' time;

(3) Reduction of the specific costs of service per client (per product sold/service provided, as well as contact with the client during the interaction).

The "robo-advisors" used by banks are much cheaper than their human counterparts, and are accessible whenever and wherever the user needs their services. Introducing the omnichannel model, banks can accumulate and analyze information about customer behavior using big data technology. By managing data collected in various forms, such as text, audio, and video, banks seek to give customers valuable advice and provide customized suggestions. Customer relationship management (CRM) solutions can be used to integrate heterogeneous data into a single system.

One of the key tasks in introducing omnichannel approaches in the banking business is the integration of all IT platforms and solutions into a single centralized data repository (operations) that will allow for seamless interaction with the client, regardless of the product and channel. That is, the client should be able to carry out any purchase or service operation at a convenient time and place, and at any stage of communication. For this, the bank must ensure the availability of a unified accounting base of products, customers, accounts, and operations (for example, by CRM), monetizing the value of its analytics and increasing the value of its brand.

Another important point in the implementation of the model is the issue of interconnecting sales plans with a motivation system for employees in different channels. Accounting and incentive systems should motivate employees to work as a team while observing the strategic interests of the bank, which will avoid seller conflict of interests when initiating transactions and contacts with a client base. The proposed omnichannel sales cost management model can be used not only in banking, but also in other retail business formats, where management can collect detailed statistics and set up a factor analysis of the conversion through the sales funnel.

Author Contributions: Both authors contributed equally.

Funding: This research received no external funding.

Conflicts of Interest: The authors declare no conflict of interest.

\section{References}

Centric Digital. 2017. 5 Realistic Strategies in Omni Channel Banking. July 21. Available online: https://centricdigital.com/blog/customer-experience/5-realistic-strategies-in-omni-channel-banking (accessed on 8 April 2019).

Dube, Apramey, and Anu Helkkula. 2015. Service experiences beyond the direct use: Indirect customer use experiences of smartphone apps. Journal of Service Management 26: 224-48. [CrossRef]

Jaakkola, Elina, Anu Helkkula, and Leena Aarikka-Stenroos. 2015. Service experience co-creation: Conceptualization, implications, and future research directions. Journal of Service Management 26: 182-205. [CrossRef] 
Klaus, Phil, and Bang Nguyen. 2013. Exploring the role of the online customer experience in firms' multi-channel strategy: An empirical analysis of the retail banking services sector. Journal of Strategic Marketing 21: 429-42. [CrossRef]

Komulainen, Hanna, and Hannu Makkonen. 2018. Customer experience in omni-channel banking services. Journal of Financial Services Marketing 23: 99-190. [CrossRef]

Komulainen, Hanna, Saila Saraniemi, Pauliina Ulkuniemi, and Marianne Ylilehto. 2018. End-customer value restructuring the financial service supply chain. Marketing Intelligence E Planning 36: 709-20.

Koneva, Anna. 2019. Chto znachit "prodavat' vezde": Omnikanal'nyye prodazhi s pomoshch'yu Ekvida. July 30. Available online: https:/www.ecwid.ru/blog/how-to-make-ecwids-omnichannel-potential-work-for-you (accessed on 7 August 2019).

Maat, Jenny. 2017. Omni-Channel Banking Begins with an Outside-in Approach. August 22. Available online: https://backbase.com/2017/08/22/omni-channel-banking (accessed on 1 September 2019).

Marketing Science Institute. 2016. Research Priorities 2016-2018. Available online: www.msi.org (accessed on 10 February 2019).

Obilisetty, Sridhar. 2019. Omnichannel Banking Goes Beyond Seamless Transactions. Available online: https://hefinancialbrand.com/73488/omnichannel-banking-data-customer-journey-experience (accessed on 3 April 2019).

Okorokov, Semon. 2016. Omnikanal'nost': Panatseya ot krizisa ili modnyy trend. June 1. Available online: https://roem.ru/01-06-2016/225473/omnikalnost (accessed on 9 April 2019).

Retail Pragmatist. 2019. The Economics of Omni-Channel Retail—What Does Omni-Channel Mean? January 5. Available online: http://www.retailpragmatist.com/economics-omni-channel-retail (accessed on 12 April 2019).

Rosman, Tobias. 2015. Investigating Omni-Channel Banking Opportunities in Sweden: From a User Perspective. Stockholm: KHT Royal Institute of Technology, School of Computer Science and Communication.

Saghiri, Soroosh, Richard Wilding, Carlos Mena, and Michael Bourlakis. 2017. Toward a three-dimensional framework for omni-channel. Journal of Business Research 77: 53-67. [CrossRef]

Sahoo, Debjani, and Sreejesh S. Pillai. 2017. Role of mobile banking servicescape on customer attitude and engagement: An empirical investigation in India. International Journal of Bank Marketing 35: 1115-32. [CrossRef]

Sberbank. 2018. Annual Report, 2017. Available online: https://www.sberbank.com/common/img/uploaded/files/ pdf/yrep/en/sberbank_annual_report_2017_eng.pdf (accessed on 1 April 2019).

Serov, Eugene R. 2018. Managing of the net cost of omni-channel sales in credit organizations. Problems of Modern Economics 3: 188-92.

Shaikh, Aijaz A., and Heikki Karjaluoto. 2015. Mobile banking adoption: A literature review. Telematics and Informatics 32: 129-42. [CrossRef]

Skan, Julian, James Dickerson, and Samad Masood. 2015. The Future of Fintech and Banking: Digitally Disrupted or Reimagined? Available online: www.accenture.com (accessed on 15 February 2019).

Tam, Carlos, and Tiago Oliveira. 2017. Literature review of mobile banking and individual performance. International Journal of Bank Marketing 35: 1044-67. [CrossRef]

Terrasoft. 2019. Omni-Channel Banking. Available online: https://www.terrasoft.ru/financial-services/insights/ omnikanalny-banking (accessed on 11 April 2019).

Tinkoff. 2018. Strategy Day, June. Available online: http://finside.ru/wp-content/uploads/tinkoff-strategy-day2018.pdf (accessed on 7 April 2019).

(C) 2019 by the authors. Licensee MDPI, Basel, Switzerland. This article is an open access article distributed under the terms and conditions of the Creative Commons Attribution (CC BY) license (http://creativecommons.org/licenses/by/4.0/). 